\title{
B101 熱供給用超小型原子炉に関する研究開発
}

\section{Research and Development on Very Small Reactor for Heat Supply}

\author{
○準 中島伸也（原研） \\ 準 小田野直光 (原研) \\ 正 楠 剛 (原研) \\ 正 落合政昭（原研）
}

\author{
Nobuya NAKAJIMA, Tsuyoshi KUSUNOKI \\ Naoteru ODANO, Masa-aki OCHIAI \\ Japan Atomic Energy Research Institute, Toukai-mura, Naka-gun, Ibaragi-ken
}

\begin{abstract}
In next century, a great deal of energy is used for pablic life in this coutry. This paper describes two new very small reactors for thermal heat supply to pulic use, such as air-conditioning and hot water. These reactor are characterized by the high safety, the long life fuel and the excellent cost performance. The reactor is an integrated and natural circulated PWR with passive safety systems. The reactor is designed with simple structure and enough isolation efficiency to be installed in the deep underground or settled on the base floor of a office building in a large
city.
\end{abstract}

Key Words: Very Small Reactor, Integrated Type, Natural Circulation Type, Self-pressurization, In-vessel type CRDM, Heat Supply, Long Fuel Life, Pasive Safety Reactor, MR-100G, MR-1G

\section{1.はじめに}

21 世紀のエネルギーを考える際、エネルギー消費量の 予測だけでなく、社会構造、地球環境、地政学的、自然災 害、エネルギ一資源等に関連して社会受容性を考慮した検 討が必要である。

エネルギー消費量については、現在、産業用が减少の、 民生用が増加の傾向を示しており、この傾向は将来も続く と考えられ、また民生用の業務用及び家庭用エネルギーの 過半は、暖房用及び給湯用として、続いて電灯・動力用が 占めている ${ }^{1)}$ 。そのため、冷房、䁔房、給湯用エネルギー 源の整備が必要である。

社会構造に関しては、人口の減少、少子高䶨化社会が確 実視され、老後の快適な生活を達成するため、高温多湿、 寒冷等四季に応じた空調のエネルギ一確保は不可欠である。 さらに、地域の自立化として、エネルギ一大消費地域が供 給面でも自立するため経済性、効率のよい小型・軽量化さ れた地域エネルギー供給システムが必要となる。

地球環境に関しては、地球温暖化、オソン層破壊等の対 策として、それらの効果ガス排出量の国際的な規制が進め られ、例えば、炭酸ガスあるいはフロンガスがその対象と なっている ${ }^{2)}$ 。しかし、代替フロンもその対象となること から、快適な生活に不可欠な空調用冷媒が大きな制限を受 け、将来的には電気式空調システムの代案を用意する必要 があろう。

地政学、自然災害については、我が国がエネルギ一資源 に乏しく、さらに島国でもあることから、天然ガス等のエ ネルギー輸入においても大きな制約を伴っている。一方、 地震国でもあることから、地震災害、特に大規模火災の発 生は、国民生活への多大な人的・資産的影響が大きく、そ
の㦟念は都市住民に強いといわれている。そのため、地震 防災に強い、裸火を用いないエネルギー様式を用いた生活 環境の整備も重要であり、この対応策はまた高齢化社会に おける不慮の事故防止にも役立つ利点を有する。

原子力エネルギー利用抾充の観点から、21 世紀の社会 を支えるに必要な民生用エネルギ一源としては、安価、長 期安定性が高い、社会受容性が優れている等が大きな要素 であり、その条件を満たすエネルギ一源として原子力利用 がその一つに考えられる。それは、少量の燃料で膨大な工 ネルギーを出す原子力の特長を生かし、冷房、暖房、給湯 用の熱源として長期利用することであり、都会などのエネ ルギー消費地に分散して配直する小型軽水炉を中核とした 地域熱供給システムを構築することである。

\section{2. 熱供給用原子炉システム}

（1）超小型原子炉の要件

21 世紀の民生用の吸収式冷凍栱、房、給湯用エネル ギ一源としての熱供給原子炉規模としては、地域熱供給用 の場合には、300〜 $500 \mathrm{MW} \mathrm{th}$ 程度であり、年間を 通しての熱負荷あるいは燃料交換等の効率を考慮すれば、 一基当たりの熱出力 $100 \mathrm{MW} \mathrm{th}$ 程度、2次系の出口温 度が $200{ }^{\circ} \mathrm{C}$ 程度の超小型に分類される原子炉 ${ }^{3)}$ を複数台 で供給できる。また地域熱供給用システムを補完する役割 として、オフィスビル等での単独の熱供給を考慮すれば、 その熱出力は約 $1 \mathrm{MW} \mathrm{t} \mathrm{h}$ の炉で十分である。熱の有効な 供給範囲は数 $\mathrm{km}$ mが限度とされ、原子炉設置用の空間確保 が重要であり、利用者との距離が近いこと、周辺の人口密 度が多いこと等が予想される。そのため、事故発生の可能 性を排除し、万が一の事故発生時においても、周辺住民の

日本機械学会〔No.00-11〕第 7 回動力・エネルギー技術シンポジウム 2000 講演論文集〔2000-10-31,11-1,・東京〕 
避難を必要としない設計が要求される。また建設、保守管 理に関しても、周辺住民の日常生活に極力影響を及ぼさな い配慮も重要であり、現地での作業時間を短縮するための 工夫が要求される。このような条件を考慮して、地域熱供 給用としては大深度地下を、オフィスビルの熱供給用とし てはビルの地下室を炉設置場所として想定する。

以上のように熱供給原子炉の要件をまとめると、

(1)限りなく受動的安全性が高いこと。

(2)小型・軽量で、現地作業時間が短いこと。

(3)長期連続運転が可能で、保守管理が容易であること。 (4)耐震性、耐火性等自然災害に対して優れていること。

(5)有効な離隔距離を確保する仕組みがあること。

(6)便利であり、安価であり、社会受容性が高いこと。 等が挙げられ、発電用原子炬とは異なった特性も要求され る。

（2）熱供給原子炉の共通する概念

熱供給用超小型原子炉への要件を満たす設計方策として、 (1)一次系は自然循環方式とする。

(2)原子炉は蒸気発生器及び制御棒駆動装置を内装する一 体型とする。

(3)自己加圧方式を採用する。

(4)ボロンによる反応度制御を行わない。

(4)設置場所の地盤あるいはビルの条件に制限が少ない。 等を原子炉構築の基本概念とした。

自然循買方式の採用は、動的機器である強制循環ポンプ が必要なく、ポンプに起因する故障を排除でき、長期連続 運転が容易になるばかりでなく、点検保守等現場作業の簡 素化が期待される。一体型の採用は、原子炉容器を貫通す る一次系配管系が不要となり、大口径配管破断事故の想定 が不必要となる。また、原子炉容器胴部を貫通する配管が なくなり、原子炉の信頼性が飛躍的に改善される。自己加 圧方式の採用は、加圧器が不要となり設置空間を小さくで き、空間確保が容易になる。さらに、ボロンを使用しない こと、一次系配管が無いこと、動的機器が無いこと等から 不純物の発生量が極めて少なくすることが可能となり運転 中の冷却水管理が不必要となり、運転保守面での大幅な改 善が期待される。さらに、地質、ビルの構造・強度に依存 する要素が少ないことを前提とし、熱供給用超小型原子炉 の利用範囲の拡大を図っている。

\section{3. 地域熱供給用超小型原子炉 (MR - $100 \mathrm{G})$}

M R-100Gは、熱消費地域の大深度地下に設置し、地上 への熱供給をおこなう。大深度としては、地下約 50 から 100 mが想定されており、耐震性にも優れ、地上の生活 空間と隔離でき、万が一の事故時においても放射能閉じ込 めへの期待が大きい。また、新たな大深度地下の公共的使 用に関する特別措置法 () により、传遇措圈も期待され、地
下空間を低価で利用できる等の利点を有している。しかし、 一般的に、我が国における大都市は河川流域の堆積層に展 開されており、地質的に安定な固結岩盤を得るためには、 $1 \mathrm{~km}$ 以上の掘削が必要であるとされていることから、末 結地盤での建設が不可欠となる。また、新規の都市開発を 除けば、地盤を選択する余地も少ないと予想されるため、 既設都市の軟弱な地盤での設置も可能とする設計が要求さ れる。

熱供給用原子炬の構築物としては、地下数 $10 \mathrm{~m}$ に原子 炉本体を設置する主空洞、水・空気浄化装置、使用済み燃 料保管用施設、蓄圧水槽内水の一時保管用夕ンク等を設置 する補助空洞及び冷房用の吸収式冷凍機、暖房あるいは給 湯用の熱交換器、冷熱・温熱用の貯蔵庫等を設置するサー ビス空洞、それらを連結する配管系、通路等のトンネルで 構成される。

主空洞は、原子炉数に応じた空洞数を必要とし、地盤と の境界部は防水策を施した鉄筋コンクリート構造とし、地 下水に起因する空洞の経年劣化対策を施す。主空洞の寸法 は高さ約 $35 \mathrm{~m}$ 、直径約 $25 \mathrm{~m}$ を想定し、内面にステンレ ス製のライナーを設けるとともに、機器搬入口の寸法は出 来る限り制限し、気密性が高い設計とする（Fig. 1 参 照）。また、原子炉の長期連続運転を想定していることか ら、個々の主空洞にはポーラクレーンを設置せず、他の主 空洞と共用の移動式フレームを採用する。地下空洞部への 建設時の機器搬入については、地下空洞周辺の自動車専用 道路あるいは絴抗を利用する。そのため、熱供給システム の中で最大径を有する機器である格納容器寸法が制限され ることとなる。補助空洞は、複数の主空洞に対して共用化 を図ることにより、システム全体の小型化が図られている。

格納容器は、全高約 $22.5 \mathrm{~m}$ 、最大外径約 $8.5 \mathrm{~m}$ の 円筒形であり、上部に高さ約 $6.7 \mathrm{~m}$ の非常時崩壊熱除去 用蓄圧水槽を含んでいる。通常運転時には、原子炉容器と 格納容器の間は真空が保持され、断熱性が保たれているが、 非常時には真空が破られ、上部の蓄圧水槽から自重及び真 空引力の自然力により水が落下し、崩壊熱が熱伝導により 炉心から除去される。また、上部の蓄任水槽は、主空洞へ の搬入時及び然料交換時に取り外しができる構造とし、燃 料交換時等には水槽内の水は補助空洞の内の水タンクに一 次保管され、容器の小型化が図られている。さらに、非常 時の冷却を補足する役割として、格納容器内の上部に配置 している補助冷却装置があり、主空洞の内壁に円周状に配 置する冷却水用水タンクにより動力装固を用いない自然循 環方式で除熱する構造としている。なお、主空洞外の地盤 温度は低温が期待されるため、金属冷却板等で放熱するこ とも㭘討している。この冷却用水タンクは燃料交換時には 炉心槽、蒸気発生器、制御棒駆動機構等の遮蔽を兼ねた一 時膡き場として利用する設計となっている。 
原子炉容器は高さ約 $12.2 \mathrm{~m}$ 、直径約 $4.3 \mathrm{~m}$ で、内 部に炉心、制御棒及び駆動装置、蒸気発生器を内装してい る。容器の上蓋は円盤状で、制御棒駆動装置の動力、位置 計測及び温度計測用のケーブルが貫通する。フランジ部に は蒸気発生器に接続する配管が貫通しており、容器胴部に はそれ以外の貫通部を有しない設計となっている。一次冷 却水は自然循環により、直管式貫流型蒸気発生器の細管側 を流れる構造である（Fig. 2 参照）。

炉心は高さ約 $1.5 \mathrm{~m}$ 、直径約 $1.4 \mathrm{~m}$ で、燃料集合体 37 体で構成されている。燃料集合体は 8 年間の長寿命を 想定し、原子炉の長期運転が図られ、燃料棒のピッチ 13 $9 \mathrm{~mm} 、 17 \times 17$ 本の燃料棒で構成される。制御棒駆動 機構は 21 体で、そのうち 12 体が停止用である。炬心の 周りには反射体が設けられ中性子の有効利用を図るととも に、非常時にはこの反射体が自然落下するとともに反射体 と一体化された中性子吸収体が降下し炉心を取囲み、减速 材温度係数が負となることへの対処としている。なお、使 用済み燃料は他の主空洞から出る燃料をまとめて補助空洞 内の保管用プールで冷却される（Table 1 参照）。

運転保守管理としては、運転中の水浄化は行わず、運転 終了後原子炉容器の蓋開放に先立って補助空洞内の水浄化 あるいは気体浄化装置を用いて所定の濃度に達して後に原 子炉容器の蓋を開放する。運転監視、保守は複数炉を一括 しておこなう事とする。

\section{4. オフィスビル熱供給用超小型原子炉（MR-1G）}

M R-1 Gは、エネルギーを集中的に使用すると考えら れるオフィスビル等の地下最下室に原子炉を設置すること を想定している。そのため、日常のオフィス作業に支障を 生じないため、燃料交換等の現地での作業は概ね2，3日 以内を目途に検討した。また、どのようなオフィスビルに も設置が可能となるよう、原子炉の設置に伴うビル自体に 酎震性等の大幅な要求を必要としない原子炉であることも 条件となる。そのため、燃料交換等を現地で行わず、原子 炉内に使用済み燃料を入れたままの状態で、地下室から搬 出し、同時に、工場で新燃料を装荷した原子炉容器を地下 室のピットに設置し、2 次系の配管を接続後、運転が再開 可能とする簡略化が図られている（Fig. 3参照）。

原子炬は燃料を装荷した状態で工場と現地間を輸送する こととなるため、一般道を通行することを想定する必要が ある。そのため、現在の使用済み燃料輸送容器の大きさ、 仕様を参考とし、格納容器を輸送用キャスクを兼ねる設計 とした。

工場から現地間の原子炉の移動については、工場にて燃 料の装荷、一次冷却水及び格納容器上部の蓄圧水槽に所定 の水量を入れ、横置き状態でトレーラーにてビルの地下に 輸送させる。現地では、地下室の原子炉ピットに設置し、
配管類の接続の後原子炉を運転する。所定の運転時間が経 過する数年後において、原子炉停止後、格納容器上部の蓄 圧水槽の水を原子炉容器と格納容器間の断熱用真空域に注 入し、放熱しながらトレーラーにて工場へ輸送する。工場 で使用済み燃料取出し後、洗浄、検査の後原子炉容器等は 再度組み立て使用するものとする。万が一ビルの地下にて 上部タンクの冷却水を落下させるような非常時の動作が入 った場合には、上記と同様な処置により、トレーラーによ り工場に輸送が行われる。なお、トレーラーによる輸送の 際には、原子炉容器が横置きとなるため、それでも炉心が 冠水し、さらに輸送中のいかなる姿勢においても炉心冠水 が維持できるよう炉心の位置、原子炉容器の寸法、冷却水 量を考慮した設計がなされている。

MR - 1 Gの原子炉、炉心、格納容器の基本的な動作原 理はMR－100 Gと同様の考えであり、出力規模に応じ た寸法が異なっている5)。

格納容器は、高さ約 $5 \mathrm{~m}$ 、直径約 $2.4 \mathrm{~m}$ の円筒状であ り、上部約 $1.5 \mathrm{~m}$ には蓄圧水槽が設置されている。また、 この格納容器は現地と工場の間を輸送する際の輸送用キャ スクを兼ねていることから、格納容器表面には鉛遮蔽体を 巻き、その周りに放熱用フィンを兼ねた衝擊吸収材を設け るとともに、格納容器上部及び下部に衝撃吸収材を設けて いる。万が一輸送時に事故が発生した際の衝撃力を吸収で き、またその状態で地下室にて利用するため地震時の構造 強度あるいは耐火性にも優れた設計となっている。これら 原子炉容器、格納容器等の総重量は約 100 トンとなって おり、トレーラーの輸送が可能な容積、重量となっている。

原子炉本体の構造は、高さ約 $2.8 \mathrm{~m}$ 、直径約 $1.3 \mathrm{~m}$ 、 蒸気発生器はヘリカルコイル式貫流型である。灯心は、高 さ約 $0.4 \mathrm{~m}$ 、直径的 $0.4 \mathrm{~m}$ であり、 4 集合体で構成さ れ、燃料ピッチは18 mmである（Table 1参照）。

運転保守管理としては、基本的に現地での運転保守は必 要ない設計としている。

$$
\text { 5.あとがき }
$$

民生用の冷房、暖房、給湯を中心とするエネルギー源と して、超小型原子炉利用の有用性について述べ、社会受容 性の高い原子炉としての要件をまとめ、その具体的な様式

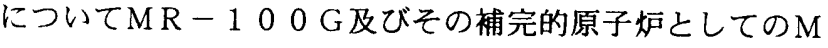
Rー1 Gについて言及した。

熱供給用超小型原子炉は、いずれも自然循環方式、一体 型とし、温度も $233^{\circ} \mathrm{C}$ と比較的低温に設定している。こ のため、動的機器、原子炉容器の貫通配管の徹底的な削减、 圧力の低隇が図られることにより、自然力を利用した長期 信頼性の高い原子炉システムの設計が可能となった。この ため、原子炉の受動安全性は高くなると同時に、小型軽量 化が図られ、コスト削減にも多大の効果が期待される。さ 
らに、大哚度地下利用に関する新法により、土地の取得、 現地工事の短縮による工事全体の効率化が更に期待される。

今後、詳細な検討をさらに進める予定であるが、大きな 技術的課題としては、長期信頼性が重要である内装型制御 棒駆動装置の開発である。原研では数年来、舶用小型原子 炉M R X等の制御棒駆動装置として内装型の開発を進めて おり、現在ほぼ設計を終了し実証試験段階にあり、それを ベースに開発を更に進める予定である。

参考文献

Table 1 Specification of Very Small Reactors

\begin{tabular}{|l|c|c|}
\hline Design Name & MR-100G & MR-1G \\
\hline Coolant System & & \\
OutletTemp. ( $\left.{ }^{\circ} \mathrm{C}\right)$ & 233 & 233 \\
Pressure (MPa) & 3.0 & 3.0 \\
\hline Thermal Power (MW) & 100 & 1 \\
\hline Containment Vessel & & \\
Diameter (m) & 8.5 & 2.4 \\
Height (m) & 22 & 5 \\
\hline No. of CRDMs & 21 & 4 \\
\hline Fuel Life Time (years) & 8 & 10 \\
\hline No. of Fuel Assemblies & 37 & 4 \\
\hline Steam Generator Type & Straight & Helical \\
& -tube & coil-tube \\
\hline
\end{tabular}

Common Specification

Reactor : Integrated Type

Cooling Mode : Natural Circulation Type

Pressurization : Self-pressurization Type

CRDM : In-vessel Type

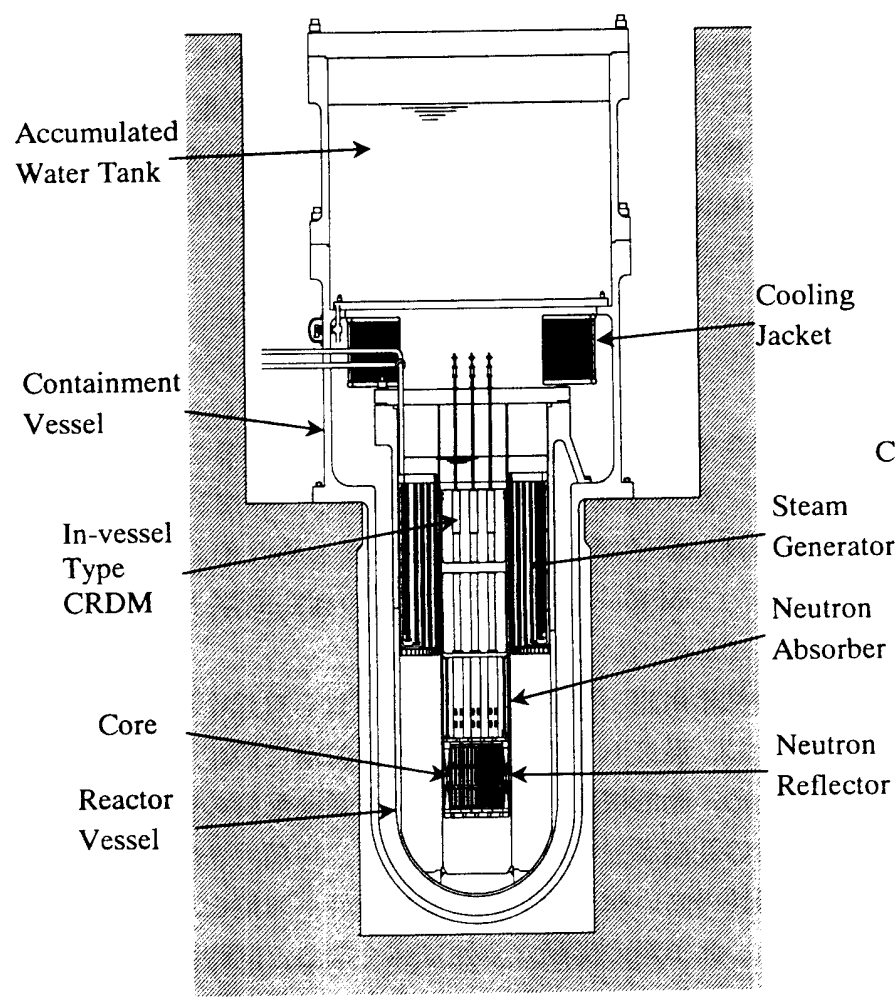

Fig.2 MR-100G Reactor
1)「エネルギー・経済統計要覧」（1999 年版）

2)「気候変動に関する国際連合枠組み条約」 京都会議議定書（１９９９７）

3 ) "Design and development status of small and medium reactor systems 1995" IAEA-TECDOC-881(1996)

4)「大深度地下の公共的使用に関する特別措置法」 (2 $\left.\begin{array}{llll}2 & 0 & 0\end{array}\right)$ 成立

5 ）楠剛 他：「ビルの熱供給に適した超小型原子炉の 概念設計」日本原子力学会誌 Vol.42、No. 11 （２００００）掲載予定

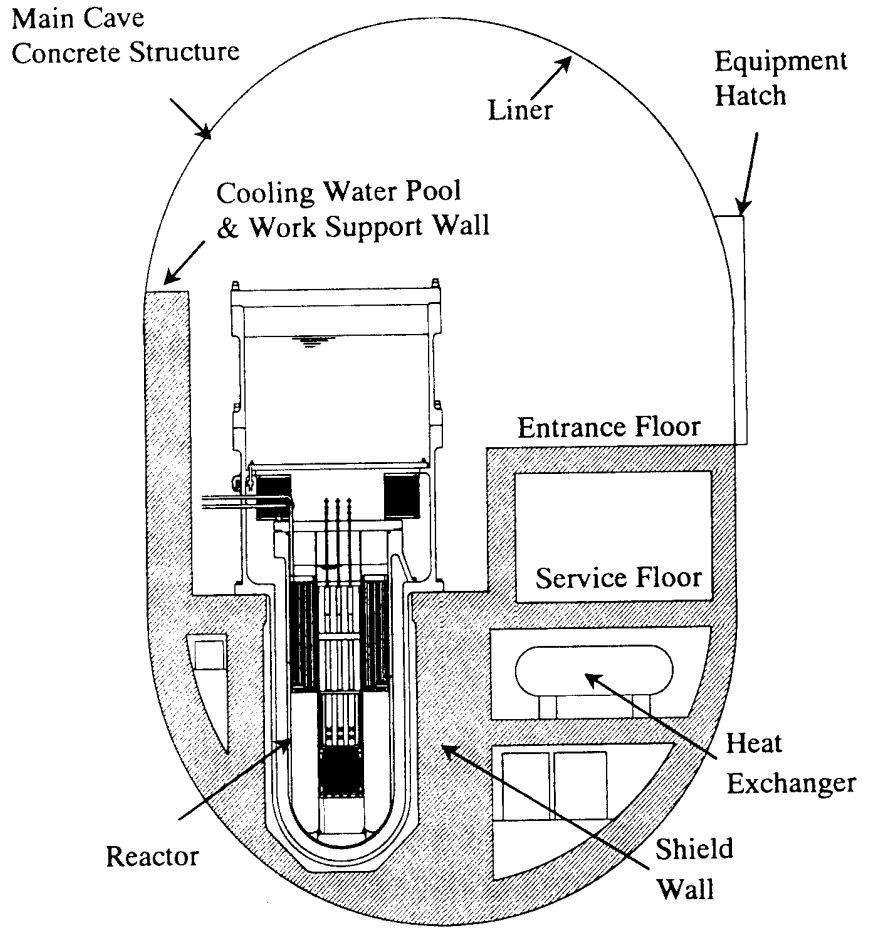

Fig. 1 MR-100G installed in Deep Underground

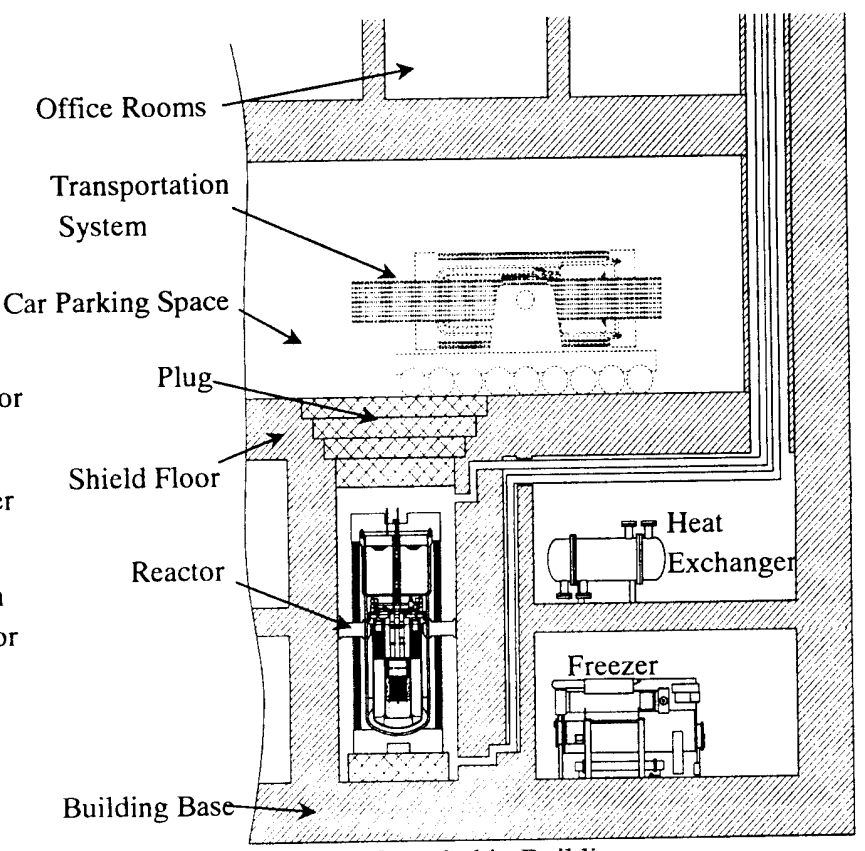

Fig.3 MR-1G settled in Building 